\title{
Pencatatan Perkawinan Di Indonesia Dikaitkan Dengan Good Governance
}

\author{
Barzah Latupono \\ Fakultas Hukum Universitas Pattimura, Ambon, Indonesia \\ E-mail: barzahlatupono75@gmail.com
}

\begin{abstract}
Marriage registration carried out by marriage registrar employees is often not in accordance with the rules set out in the Act. The law requires that the marriage record be carried out if it has fulfilled the legal requirements for marriage. There are cases of marriages that do not meet the legal requirements of marriage and there are also marriages that meet the legal requirements of marriage but are not stated. State apparatus in various service sectors, especially those concerning the fulfillment of civil rights and basic needs of the community, must be carried out in accordance with the mandate of the 1945 Constitution. Marriage records, such as the making of National Identity Cards or Driving Permits, actually discuss public services that are the responsibility of the state. So that it should pay attention to the principle of good governance, one of which is to establish costs that are in accordance with the standard of living of the people and procedures that are not user-friendly.
\end{abstract}

Keywords: Marriage Registration, Good Governance

\section{A. PENDAHULUAN.}

Jika melihat persoalan perkawinan di Indonesia, maka hukum perkawinan di Indonesia diatur melalui Undang-Undang No 1 Tahun 1974 tentang Perkawinan. UU ini terdiri dari 14 bab dan 67 pasal, dan untuk implementasinya dilengkapi dengan Peraturan Pemerintah No. 9 Tahun 1975 tentang peraturan pelaksanannya dan dinyatakan berlaku efektif sejak tanggal 1 Oktober 1975.

Pada prinsipnya sebuah perkawinan dapat dikatakan sah secara hukum apabila memenuhi 2 (dua) syarat yaitu , baik syarat materiil maupun formil. Di Indonesia, syarat sahnya suatu perkawinan diatur dalam UndangUndang Nomor: 1 Tahun 1974 tentang Perkawinan. Dalam Undang-undang ini, tepatnya di dalam Pasal 2 diatur bahwa sebuah perkawinan sah secara hukum apabila dilakukan menurut hukum agama dan kepercayaan dari masing-masing pihak yang akan menikah dan dicatat menurut peraturan perundang-undangan 
yang berlaku.

Syarat materiil dari sebuah perkawinan yang dimaksud dalam pasal ini adalah bahwa perkawinan yang akan dilakukan sah menurut agama masingmasing pihak. Apabila perkawinan akan dilakukan oleh pasangan yang berbeda agama, maka kembali lihat kepada hukum agama masing-masing pihak. Bahwa sebagaimana diatur dalam ketentuan Pasal 10 PP No. 9 Tahun 1975 dinyatakan, perkawinan baru dapat dikatakan sah secara hukum apabila dilakukan di hadapan pegawai pencatat dan dihadiri dua orang saksi. Dan tata cara perkawinan dilakukan menurut hukum masing-masing agamanya dan kepercayaannya. Di Indonesia, sebuah perkawinan wajib di daftarkan (di catat) di instansi yang telah ditentukan (KUA bagi pasangan beragama Islam dan Kantor Catatan Sipil bagi pasangan yang beragama Non-Islam). Dalam hal ini setiap pasangan yang akan mencatatkan perkawinannya wajib memilih salah satu instansi ini.

Persoalan pencatatan perkawinan. Dalam pasal 2 ayat (2) dinyatakan bahwa "Tiap-tiap perkawinan dicatat menurut peraturan perundang-undangan yang berlaku". Peran pemerintah hanya sebatas melakukan pencatatan nikah dan hal tersebut berarti pemerintah hanya mengatur aspek administratif perkawinan. Namun, dalam prakteknya, kedua ayat dalam pasal 2 tersebut berlaku secara kumulatif sehingga kedua-duanya harus diterapkan bagi persayaratan sahnya suatu perkawinan. Hal ini boleh jadi merupakan konsekwensi dari sistematika produk perundang-undangan dimana komponen-komponen yang menjadi bagiannya tidak dapat dipisah-pisahkan satu sama lain. ${ }^{1}$

Akibatnya menurut Mubarok $^{2}$, meskipun suatu perkawinan sudah

1 Sudarsono. (1994). Hukum Perkawinan Nasional, Jakarta: Rineka Cipta, h.

2 Mubarok, Jaih. (2002). Metodologi Ijtihad Hukum Islam, Yogyakarta: UII Press, dipandang sah berdasarkan aturan agama tertentu, tetapi kalau belum dicatatkan pada kantor pemerintah yang berwenang (baik Kantor Urusan Agama/KUA untuk yang beragama Islam ataupun Kantor Catatan Sipil/KCS untuk yang diluar Islam), maka perkawinan tersebut belum diakui sah oleh negara. Dalam berbagai kasus, sahnya suatu perkawinan secara yuridis memang harus dibuktikan melalui buku nikah yang diperoleh dari KUA dan KCS. Hal ini tentu saja menimbulkan implikasi hukum dan sosial yang beragam bagi pasangan yang berbeda agama seperti misalnya anak-anak yang lahir tidak akan dianggap sebagai keturunan yang sah dan suami-istri pun mengalami kesulitan memperoleh hakhak keperdataan yang timbul dari perkawinan tersebut.

Pelaksanaan perkawinan di luar negeri memberikan ruang yang dapat digunakan sebagai sarana untuk melegalkan perkawinan beda agama. Pasal 56 Undang-Undang Perkawinan mengatakan bahwa perkawinan yang dilangsungkan diluar Indonesia antara dua orang warga negara Indonesia atau seorang warga negara Indonesia dan warga negara asing adalah sah bilamana dilakukan menurut hukum yang berlaku dimana perkawinan itu dilangsungkan dan bagi warga negara Indonesia tidak melanggar ketentuan Undang-Undang Perkawinan dan selanjutnya disebutkan bahwa dalam waktu satu tahun suamiistri tersebut kembali ke wilayah Indonesia surat bukti perkawinan mereka harus didaftarkan pada kantor pencatatan perkawinan di tempat tinggal mereka, namun perkawinan itu tetap dianggap tidak sah sepanjang belum memenuhi ketentuan yang diatur oleh agama, artinya mereka harus tetap memperhatikan aspek hukum agama dan $\mathrm{UU}^{3}$.

Perkawinan yang tidak

${ }^{3}$ Darmabrata, Wahyono. (2003). Tinjauan UU No 1 Tahun 1974 Tentang Perkawinan Beserta Undang-Undang dan Peraturan pelaksanaanya, Jakarta: Gitama Jaya, h. 102 
mendapatkan pengakuan negara akan mendapatkan kesulitan untuk mendapatkan Kartu Keluarga (KK), akta kelahiran anak, KTP, surat nikah dan hak pendidikan. Ini artinya keluarga tersebut kehilangan hak sipilnya sebagai warga negara. Dalam hal nikah siri atau perkawinan yang tidak dicatatkan dalam administrasi Negara mengakibatkan perempuan tidak memiliki kekuatan hukum dalam hak status pengasuhan anak, hak waris, dan hak-hak lainnya sebagai istri yang sah, yang merugikan pihak perempuan.

Setiap warga negara tidak akan pernah bisa menghindar dari berhubungan dengan birokrasi pemerintah. Pada saat yang sama, birokrasi pemerintah adalah satu-satunya organisasi yang memiliki legitimasi untuk memaksakan berbagai peraturan dan kebijakan menyangkut masyarakat dan setiap warga negara. Itulah sebabnya pelayanan yang diberikan oleh birokrasi pemerintah menuntut tanggungjawab moral yang tinggi. Pelayanan yang diberikan oleh birokrasi pemerintah, kualitasnya cenderung lemah sehingga semua orang mau tidak mau harus menerima apa adanya. Terlebih lagi dalam budaya masyarakat yang paternalistik, kedudukan para pejabat birokrasi dalam masyarakat seringkali dipersepsikan jauh lebih tinggi di atas kedudukan warga pada umumnya. Akibatnya, para pejabat birokrasi bukannya melayani warga dengan baik tetapi justru sebaliknya, berharap memperoleh pelayanan dari warga. (Dwiyanto, 2005: 375-376).. Dari beberapa pandangan budaya yang sedikit keliru ini, dapat membawa kepada penyimpangan tugas dan layanan yang sepatutnya diberikan kepada pelanggan atau masyarakat. Selain itu karena selama ini birokrasi diidentikkan dengan kinerja yang belit-belit, struktur yang tambun, penuh dengan kolusi, korupsi dan nepotisme, serta tak ada standar yang pasti (Sutiono \& Sulistiyani, 2004: 1).
Salah satu faktor yang harus ada agar dapat diselenggarakan pelayanan yang berkualitas yaitu kesadaran moral aparat sebagai abdi masyarakat dengan mempelajari budaya organisasi publik atau budaya pelayanan yang berorientasi kepada kepentingan pelanggan bukan lebih mementingkan kepentingan pimpinan. Perilaku yang buruk dari birokrasi pemerintah sering muncul karena mempunyai mindset yang salah, yang mendorong para pejabat melakukan tindakan yang tidak sesuai. Untuk membangun budaya baru dalam birokrasi maka pemerintah dapat menggali nilainilai dan tradisi yang dianggap baik dari praktek pemerintah sebelumnya kemudian mentransfernya dalam kehidupan birokrasi pemerintah sekarang yang lebih baik. Selain itu pemerintah juga dapat belajar dari best practices yang ada di negara-negara lain, yang dapat dipelajari dan ditiru, untuk dikembangkan dalam birokrasi pemerintah yang lebih unggul.

Pelayanan administratif di bidang akta nikah khususnya di Kantor Urusan Agama dan kantor catatan Sipil Kecamatan, berperan cukup besar. Dalam dasar - dasar perkawinan menyatakan perkawinan bertujuan untuk mewujudkan kehidupan rumah tangga yang sakinah, mawaddah, dan rahmah. Perkawinan juga bertujuan menghindari diri dari fitnah antara satu sama lain, sehingga dalam pelaksanaannya perlu ada wali dan saksi. Selain itu agar tidak terjadi kekhilafan/kesalahpahaman, maka perkawinan harus dicatat. Pencatatan perkawinan tersebut dilakukan oleh Pegawai Pencatat Nikah dan kantor catatan sipil. Pencatatan perkawinan dari mereka yang melangsungkan perkawinannya, bagi yang Muslim pencatatan akta nikah dilakukan oleh Pegawai Pencatat sebagaimana dimaksud dalam Undang-undang No. 32 Tahun 1954 tentang Pencatatan Nikah, Talak dan Rujuk. Setiap perkawinan harus dilangsungkan dihadapan dan di bawah 
pengawasan Pegawai Pencatat Nikah. Perkawinan hanya dapat dibuktikan dengan Akta Nikah yang dibuat oleh Pegawai Pencatat Nikah.

Adapun tugas pencatatan akta nikah adalah tugas Kantor Urusan Agama di setiap Kecamatan, dimana dalam pelaksanaan dan pelayanannya harus miningkatkan mutu pelayanan sehingga tidak terjadi penyimpangan bagi pelanggan seperti senang kawin siri dibanding mengurus akta nikah yang prosedurnya berbelit-belit dan tarifnya pun tidak jelas pula. Tentang biaya pencatatan nikah atau tarif yang harus dibayar, dalam buku Pedoman Pegawai Pencatat Nikah (PPN) telah menentukan biaya pencatat nikah, dengan tarip dimana tercamtum bahwa Peraturan Pemerintah nomor 51 tahun 2000 tanggal 1 Juli 2000 menyebutkan bahwa biaya pencatatan nikah di KUA Kecamatan sebesar Rp. 30.000 (tiga puluh ribu rupiah), namun pada prakteknya lain. Pernikahan massal merupakan fenomena kaum miskin yang semakin terpinggirkan oleh mahalnya biaya birokrasi”. Mereka bukan tidak ingin menikah secara sah, baik dari sisi agama maupun negara. Akan tetapi, kemampuan kantong mereka terbatas. Kondisi ini berbahaya bagi kelangsungan hidup mereka sebagai warga negara ${ }^{4}$.. Dari beberapa kasus diatas terdapat banyak alasan kenapa terjadinya nikah siri (perkawinan bawah tangan tanpa akta nikah) sedangkan syarat yang lain menurut agama telah memenuhi. Alasannya antara lain, biaya administrasi yang mahal, prosedur berbelit-belit atau untuk menghindari dari hukum khususnya bagi pegawai negeri dan ABRI.

Pada dasarnya birokrasi merupakan mata rantai yang menghubungkan pemerintah dengan rakyatnya, dan birokrasi merupakan alat pemerintah yang bekerja untuk kepentingan

$4 \quad$ http://www.kompas.com/kompascetak/0603/25/Jabar/ 764.htm. (Diakses pada Tanggal 4 April 2018) masyarakat secara keseluruhan. Dalam posisi demikian, maka tugas birokrasi adalah memberikan pelayanan kepada masyarakat dan merealisasikan setiap kebijakan pemerintah dalam mencapai kepentingan masyarakat. Oleh sebab itu,pemerintah telah mengeluarkan UU No.24/2013 tentang Administrasi Kependudukan yang memuat pengaturan dan pembentukan sistem yang mencerminkan adanya reformasi di bidang administrasi kependudukan dan pencatatan sipil.

Berdasarkan UU No.24/2013 tentang Administrasi Kependudukan tersebut, maka pendaftaran penduduk meliputi : Pencatatan Biodata dan Nomor Induk Kependudukan, Pendaftaran Peristiwa Kependudukan, Pendataan Penduduk RentanAdministrasi Kependudukan, Pelaporan Penduduk yang tidak mampu mendaftarkan sendiri. Adapun pencatatan sipil meliputi : Pencatatan Kelahiran, Pencatatan Lahir Mati, Pencatatan Perkawinan, Pencatatan Pembatalan Perkawinan, Pencatatan Perceraian, Pencatatan Pembatalan Perceraian, Pencatatan Kematian, Pencatatan Pengangkatan Anak, Pengakuan Anak, dan Pengesahan Anak, Pencatatan Perubahan Nama, dan Perubahan Status Kewarganegaraan, Pencatatan Peristiwa Penting Lainnya, Pelaporan Penduduk yang Tidak Mampu Melaporkan Sendiri.

Dalam rangkan penataan dan ketertiban administrasi Kependudukan, diperlukan suatu sistem registrasi penduduk dengan menggunakan Sistem Informasi Administrasi Kependudukan (SIAK) dimana data penduduk terekam dalam data base yang dimutakhirkan secara terus menerus manakala ada perubahan yang diakibatkan oleh peristiwa kependudukan dan peristiwa penting yang dialami penduduk. Catatan dibuat bagi setiap individu dan perubahan-perubahan yang dilakukan selama masa hidupnya, catatan yang dibuat untuk pencatatan sipil, peristiwa 
kelahiran,perkawinan, perceraian, dan kematian, serta pengakuan anak.

Data penduduk dicatat dalam register akta dan diterbitkan kutipan akta, sedangkan untuk peristiwa penting lainnya seperti pengangkatan anak, pengesahan anak, perubahan nama, perubahan status kewarganegaraan, dan perubahan peristiwa penting lainnya (jenis kelamin), cara pencatatan berupa catatan pinggir pada akta-akta yang dimiliki oleh penduduk, dengan demikian secara spesifik konsep kependudukan dan pencatatan sipil yang dimaksudkan dalam studi ini adalah suatu sistem registrasi yang menghasilkan dokumen kependudukan antara lain Kartu Tanda Penduduk dan Akta Kelahiran.

Dengan akta kelahiran, setiap anak yang lahir harus mempunyai kepastian hokum dalam hal asal usul keturunan, status hukum, dan kewarganegaraan. Di samping itu,akta kelahiran juga merupakan akta dasar yang dikemudian hari menjadi persyaratanpengurusan berbagai keperluan yang bernilai hukum. Dalam UUD 1945 Pasal 28 ayat (1) amandemen kedua dan Pasal 34 ayat (3)amandemen keempat telah mengamanatkan negara wajib melayani setiap warganegara dan penduduk untuk memenuhi kebutuhan dasarnya dalam rangka pelayanan umum dan meningkatkan kesejahteraan masyarakat.

Oleh karena itu, penyelenggaraan pelayanan publik yang dilaksanakan oleh aparatur negara dalam berbagai sektor pelayanan terutama yang menyangkut pemenuhan hak-hak sipil dan kebutuhan dasar masyarakat, wajib dilaksanakan sesuai dengan amanat UUD 1945 tersebut. Di samping itu, dalam Surat Edaran Menteri Pendayagunaan Aparatur Negara Nomor: 10/M.PAN/07/2005 tentang Prioritas Peningkatan Kualitas Pelayanan Publik, administrasi kependudukan dan pencatatan sipil memperoleh prioritas pertama dalam penanganan peningkatan kualitas pelayanan yang sangat diperlukan oleh masyarakat. Ini artinya bahwa, pelayanan publik dalam bidang kependudukan dan pencatatan sipil selama ini paling banyak mendapat keluhan dari masyarakat.

Kadangkala dalam urusan pencatatan perkawinan yang dilakukan oleh pegawai pencatat perkawinan sering tidak sesuai dengan aturan yang sudah ditetapkan dalam Undang-Undang. Undang-undang mensyaratkan bahwa pencatatan perkawinan itu dilakukan bila telah memenuhi syarat sahnya perkawinan ada kasus yang terjadi perkawinan belum memenuhi syarat sahnya perkawinan sudah dicatatakan dan ada juga perkawinan yang sudah memenuhi syarat sahnya perkawinan tapi tidak dicatatakan, selain itu pertimbangan tidak dicatatkan perkawinan oleh masyarakat karena:

1. Faktor biaya yang sangat mahal minimal sekitar Rp. 500,000 (lima ratus ribu rupiah) atau $\mathrm{Rp} 600,000$ (enam ratus ribu rupiah) .

2. Faktor lokasi ke KUA (Kantor Urusan Agama) maupun KCS (Kantor Catatan Sipil) yang letaknya 30 Kilometer dari desa setempat yang dinilai cukup jauh untuk dicapai oleh anggota masyarakat setempat yang mata pencahariannya mayoritas sebagai petani.

Hal yang signifikan di dalam memahami persoalan pencatatan perkawinan yang merupakan tanggung jawab negara dalam melindungi dan menjamin hak-hak warganya.

Berdasarkan apa yang diuraikan, maka permasalahan atau isu hukum dalam penulisan ini adalah Apakah pencatatan perkawinan sudah sesuai dengan asas good governance?

\section{B. PEMBAHASAN}

\section{Fungsi Pencatatan Perkawinan}

Perkawinan selanjutnya disebut 
pernikahan, merupakan sebuah lembaga yang memberikan legimitasi seorang pria dan wanita untuk bisa hidup dan berkumpul bersama dalam sebuah keluarga. Ketenangan atau ketenteraman sebuah keluarga ditentukan salah satunya adalah bahwa pernikahan itu harus sesuai dengan dengan tuntutan masing-masing agama. Bagi yang beragama Islam pencatatan dilakukan oleh KUA(kantor urusan agama) dan yang beragama selain Islam dicatat dipencatatan sipi (KCS). Pencatatan perkawinan pada prinsipnya merupakan hak dasar dalam keluarga. Selain itu merupakan upaya perlindungan terhadap isteri maupun anak dalam memperoleh hak-hak keluarga seperti hak waris dan lain-lain.

Pembentukan peraturan perundangundangan tentang pencatatan sipil tidak terlepas dari kebutuhan masyarakat akan pentingnya pencatatan untuk menentukan sahnya suatu perkawinan:

1) Peraturan Pemerintah Nomor 9 Tahun 1975 tentang Pencatatan Talak, Nikah dan Rujuk.

Menurut Pasal 2 Peraturan Pemerintah ini mengatur bahwa:

a) Pencatatan perkawinan dari mereka yang melangsungkan perkawinan menurut agama Islam dilakukan oleh pegawai pencatat sebagaimana dimaksudkan dalam UU No 32 Tahun 1954 tentang pencatatan nikah, talak dan rujuk

b) Pencatatan perkawinan dari mereka yang melangsungkan perkawinan menurut agama dan kepercayaannya itu selain agama Islam dilakukan oleh pegawai pencatatan perkawinan pada Kantor catatan sipil sebagaimana dimaksud dalam berbagai peraturan perundangundangan mengenai pencatatan perkawinan.

Berdasarkan ketentuan ini, maka pencatatan perkawinan hanya dilakukan oleh dua instansi yaitu pegawai pencatatan nikah, talak dan rujuk dan kantor catatan sipil/instansi pejabat yang membantunya Pasal 2 ayat (1) dan ayat (2) Peraturan Pemerintah No 9 Tahun 1975. Mengenai hal yang berhubungan dengan tata cara pencatatan perkawinan menurut penjelasan Pasal 2 ayat (3) pada dasarnya dilakukan sesuai dalam ketentuan tersebut dari Pasal 3 sampai dengan Pasal 9.

Adapun tahapan atau proses pencatatan perkawinan yang diatur dalam PeraturanPemerintah Nomor 9 Tahun 1975 antara lain;

a) Memberitahukan kehendak dilangsungkannya

perkawinan secara lisan maupun tulisan oleh calon mempelai atau orang tua atau walinya. Pemberitahuan memuat identitas dan disampaikan 10 (sepuluh hari) sebelum perkawinan dilangsungkan. (Pasal 4 dan 5 PP Nomor 9 Tahun1975);

b) Setelah semua persyaratan dipenuhi dan tidak ada halangan untuk melangsungkan perkawinan menurut Undang-undang, maka perkawinan tersebut dimasukkan dalam buku daftar dan diumumkan.(Pasal 6, 7, 8 dan 9 PP Nomor 9 Tahun 1975.);

c) Setelah perkawinan dilangsungkan, kedua mempelai harus menandatangani Akta Perkawinan yang dihadir dua saksi dan pegawaipencatat perkawinan. Sedangkan yang beragama Islam akta tersebutjuga ditanda tangani 
oleh wali nikah. (Pasal 12 dan 13 PP Nomor 9 Tahun 1975.);

d) Untuk memberikan kepastian hukum kepada kedua mempelai, masing-masing diserahkan kutipan akta perkawinan sebagai alat bukti. Selanjutnya, setelah dipenuhinya tata cara dan syarat-syarat pemberitahuan serta tidak ditemukan suatu halangan untuk perkawinan, pegawai pencatat mengumumkan dan menandatangani

pengumuman tentang pemberitahuan kehendak melangsungkan perkawinan dengan cara menempel surat pengumuman pada suatu tempat yang sudah ditentukan dan mudah dibaca oleh umum.

Secara garis besar, perkawinan yang tidak dicatatkan sama saja dengan membiarkan adanya hidup bersama di luar perkawinan, dan ini sangat merugikan para pihak yang terlibat (terutama perempuan), terlebih lagi kalau sudah ada anak-anak yang dilahirkan. Mereka yang dilahirkan dari orang tua yang hidup bersama tanpa dicatatkan perkawinannya, adalah anak luar kawin yang hanya mempunyai hubungan hukum dengan ibunya, dalam arti tidak mempunyai hubungan hukum dengan bapaknya. Dengan perkataan lain secara yuridis tidak mempunyai bapak.

Sebenarnya, tidak ada paksaan bagi masyarakat untuk mencatatkan perkawinan. Dalam artian, jika kita tidak mencatatkan perkawinan, bukan berarti kita melakukan suatu kejahatan. Namun jelas pula bahwa hal ini memberikan dampak atau konsekuensi hukum tertentu yang khususnya merugikan perempuan dan anak-anak.

Bersinggungan dengan pentingnya pencatatan perkawinan, seperti juga pembuatan KTP atau SIM, kita sesungguhnya membicarakan pelayanan public yang menjadi tanggung jawab negara. Sehingga sudah semestinya memperhatikan prinsip good governance, salah satunya adalah menetapkan biaya yang sesuai dengan taraf kehidupan masyarakat dan prosedur yang tidak berbelit-belit (user-friendly). Dengan prosedur yang tidak berbelit-belit dan biaya yang sesuai masyarakat diajak untuk mencatatkan perkawinannya.

2) Undang-Undang No. 24 Tahun 2013 tentang Administrasi Kependudukan.

UU Administrasi Kependudukan ini yang mengatur tentang tata cara dan tata laksana pencatatan peristiwa penting atau pencatatan sipil yang dialami oleh setiap warga negara Indonesia. Yang dimaksud dengan peristiwa penting menurut undang-undang ini adalah sebagaimana tercantum dalam pasal 1 angka 17 bahwa: kejadian yang dialami oleh seorang meliputi kelahiran, kematian, lahir mati, perkawinan, perceraian, pengakuan anak, pengesahan anak, pengangkatan anak, perubahan nama dan perubahan status kewarganegaraan.

Pencatatan perkawinan menurut Pasal 34 UU ini menentukan bahwa:

(1) Perkawinan yang sah menurut peraturan perundangundangan wajib dilaporkan oleh penduduk kepada instansi pelaksana ditempat terjadinya perkawinan paling lambat 60 hari sejak tanggal perkawinan.

(2) Berdasarkan laporan sebagaimana yang dimaksud pada ayat (1) pejabat pencatatan sipil mencatat pada register akta perkawinan 
dan menerbitkan kutipan akta perkawinan.

(3) Kutipan akta perkawinan sebagaimana yang dimaksud pada ayat (2) masing-masing diberikan kepada suami-istri.

(4) Pelaporan sebagimana yang dimaksud pada ayat (1) bagi penduduk yang beragama Islam dilakukan oleh KUA Kecamatan.

(5) Data hasil pencatatan peristiwa sebagaimana dimaksud pada ayat (4) dan dalam pasal 8 ayat (2) wajib disampaikan oleh KUA Kecamatan kepada instansi pelaksana dalam waktu paling lambat 10 (sepuluh) hari setelah pencatatan perkawinan dilaksanakan.

(6) Hasil pencatatan data sebagaimana dimaksud pada ayat (5) tidak memerlukan kutipan akta pencatatan sipil.

(7) Pada tingkat kecamatan laporan sebagaimana dimaksud pada ayat (1) dilakukan pada UPTD instansi pelaksana.

\section{Pemerintahan Yang Baik}

Pada dasarnya sistem administrasi kependudukan merupakan sub sistem dari sistem administrasi Negara, yang mempunyai peranan penting dalam pemerintahan dan pembangunan penyelenggaraan administrasi kependudukan. Hak asasi setiap orang di bidang pelayanan administrasi kependudukan, peningkatan kesadaran penduduk dan kewajibannya untuk berperan serta dalam pelaksanaan administrasi kependudukan, pemenuhan data statistik kependudukan dan statistic peristiwa kependudukan, dukungan terhadap perencanaan pembangunan sistem administrasi kependudukan guna meningkatkan pemberian pelayanan public tanpa diskriminasi.
Sejalan dengan arah penyelenggaraan administrasi kependudukan, maka pendaftaran penduduk dan pencatatan sipil sebagai sub-sub sistem pilar dari administrasi kependudukan perlu ditata dengan sebaik-baiknya agar dapat memberikan manfaat bagipemerintah.

Pengelolaan pendaftaran penduduk merupakan tanggung jawab pemerintah kabupaten/kota dimana dalam pelaksanaanya diawali dari desa/kelurahan selaku ujung tombak pendaftaran penduduk. Dalam pelayanan tersebut perlu dilakukan dengan benar dan cepat agar penduduk merasa mendapatkan pelayanan yang memuaskan. Pencatatan biodata penduduk diarahkan pada pemenuhan data dari setiap penduduk dan keluarga yang merupakan tanggung jawab pemerintah kabupaten/kota. Data tersebut merupakan sumber basis data kependudukan secara nasional yang menjadi tanggung jawab pusat (dalam hal ini Direktorat Jenderal Administrasi Kependudukan).

1) Lahirnya Prinsip Good Governance

Lahirnya prinsip Good Governance dari adanya kepentingan lembaga donor seperti PBB, bank dunia, ABD maupun INF dan dalam perkembangan selanjutnya Good Governance ditetapkan sebagai sayarat bagi negara yang membutuhkan pinjaman dana sehingga digunakan sebagai standar pembangunan berkelanjutan dan berkeadilan. ${ }^{5}$ Konsep good governance ini tidak terlepas dari adanya konsep governance yang terkait dengan management publik dan korupsi. Istilah governance dalam literatur.

2) Ciri Kharakteristik Good Governance

5 Sumartono, Hafifah Sj. (2003) Inovasi, Partisipasi Dan GD, Jakarta: Yayasan Obor Indonesia, h. 5 
Permasalahan pemerintah menjadi suatu perdebatan, karena adanya dinamika yang menuntut perubahan-perubahan baik pada pemerintah maupun pada masyarakat, perubahan diharapkan agar pemerintah menjadi lebih demokratis dalam menjalankan fungsi pelayanan publik serta mampu menyusun kebijakan program yang dapat menjamin kepastian hukum dan perlindungan kepada masyarakat.

UNDP merumuskan karekteristik pemerintahan yang baik sebagai berikut. ${ }^{6}$

a) Partisipasi (Participation)

Setiap WN mempunyai hak dan kewajiban utuk mengambil bagian dalam proses bernegara, berpemerintah serta bermasyarakt, baik langsung maupun melalui intermediasi institusi legitimasi yang mewakili kepentingannya . partisipasi $\mathrm{WN}$ ini dilakukan tidak hanya pada tahapan implementasi akan tetapi secarah menyeluruh mulai dari tahapan penyususnan kebijakan, pelaksanaan, evaluasi serta pemanfaatan hasil-hasilnya.

b) Penegakan hukum (rule of law) Good governance dilaksanakan dalam rangka demokratisassi kehidupan berbangsa dan bernegara. Salah satu syarat kehidupan demokrasi adalah adanya penegakan hukum yang adil dan dilaksanakan tanpa pandang buluh oleh karena itu langkah awal penciptaan good governance adalah: membangun sistim hukum yang sehat baik perangkat lunak (soft ware), perangkat keras (hard ware) maupun sumber daya manusia

6 UNDP merumuskan karekteristik pemerintahan yang baik. (GG), (UNDP dalam sadu wassistiono ,kapita salekta penyelenggaraan pemerintah daerah, h. 33-35. yang menjalankan sistimnya (human ware)

c) Transparansi (transparancy)

Keterbukaan adalah merupakan salah satu karakteristik good governance terutama adanya semangat zaman serba terbuka dan akibat adanya refolusi informasi keterbukaan mencakup semua kepentingan publik.

d) Daya tanggap (responsivenes)

Responsivenes sebagai konsekwensi logis dari keterbukaan maka setiap komponen yang terlibat dalam proses pembangunan good governance perlu memeliki daya tanggap terhadap keinginan maupun keluhan setiap stakeholders

e) Consensus (orentation)

Good governance menjadi perantara kepentingan yang berbeda untuk memperoleh pilihan terbaik bagi kepentingan yang lebih luas, baik dalam hal kebijakan maupun prosedur.

f) Keadilan (equity)

Semua warga negara mempunyai kesempatan yang sama untuk memperoleh kesejatraan.

g) Effectiveness And Efficiency

Proses dalam lembaga menghasilkan sesuai dengan apa yang telah digariskan dengan menggunakan sumber yang tersedia sebaik mungkin

h) Akuntabilitas (accountability)

Para pembuat keputusan dalam pemerintah, sektor swasta dan masyarakat (civil society) bertanggung jawab pada publik dan lembaga stekholders. Akuntabilitas ini tergantung pada organisasi tersebut untuk kepentingan internal atau eksternal organisasi

i) Visi Strategis (strategic vision) Para pemimpin dan publik harus mempunyai prespektif good 
governance dan pengembangan manusia yang luas serta jauh kedepan sejauh dengan apa yang diperlukan untuk pembangunan.

\section{Good Governance di Indonesia dan Maladministrasi}

Reformasi yang terjadi pada pertengahan tahun 1998 membawa perubahanyang signifikan terhadap proses penyelenggaraan pemerintahan. Hal ini juga terjadi didalam birokrasi yang merupakan organisasi pemerintah dalam menjalankan tugas-tugas pemerintahan dan pemberian pelayanan langsung kepada masyarakat. Gerakan reformasi menghendaki birokrasi memiliki netralitas politik, transparan, responsif,dan akuntabel. Dengan tuntutan ini, otomatis birokrasi harus membangun frame dan karakteristik baru dalam menjalankan tugasnya sesuai dengan amanat yang dikehendaki rakyat. Namun harapan publik untuk melihat adanya perbaikan kualitas pelayanan publik dalam bidang kependudukan dan pencatatan sipil sering tidak terwujud. Hal ini disebabkan stigma negatif yang melekat pada birokrasi pemerintah sebagai suatu penyakit (bureau patology) yang diikuti dengan prosedur yang berbelit-belit,lambatnya pelayanan, dan korupsi dengan beranekaragam bentuknya.

Di samping itu juga karena paradigma yang selalu melekat pada para birokrat selalu cenderung menganggap sebagai abdi negara dari pada sebagai abdi masyarakat.

Padahal idealnya bahwa, pemerintah pada hakikatnya memberikan pelayanan kepada masyarakat. Pemerintah tidaklah diadakan untuk melayani diri sendiri, tetapi untuk melayani masyarakat.

Birokrat sebagai pelaksana penyelenggara negara serta pelayan masyarakat harus dapat memenuhi keinginan dan kebutuhan masyarakat agar ketertiban dan keadilan di dalam masyarakat dapat tercapai. Di samping itu tujuan birokrasi bukanlah hanya sekedar pelayanan publik. Pelayanan publik hanyalah merupakan salah satu manifestasi fungsi birokrasi. Membatasi fungsi birokrasi hanya pada pelayanan publik akan menjadikan birokrasi berfungsi pada level teknis rutin dan jangka pendek. Padahal birokrasi tidak hanya melayani tujuan teknis rutin dan jangka pendek, namun birokrasi dibentuk dalam rangka untuk tercapainya tujuan bangsa dan negara. Untuk mencapai tujuan negara tersebut, diperlukan berbagai sarana pendukung, dalam hal ini salah satunya adalah sarana hukum, khususnya hokum administrasi negara, yang mengatur dan memungkinkan administrasi negara untuk menjalankan fungsinya dan melindungi warga terhadap sikap tindak administrasi negara itu sendiri.

Mal administrasi sangatlah diperlukan dalam perkembangan hukum administrasi karena selain untuk menjadi satu parameter dalam menentukan ada tidaknya kesalahan pribadi atau kesalahan jabatan dalam menjalankan suatu tugas dan tanggungjawab yang dibebankan negara juga maladministarasi untuk menentukan apakah suatu perbuatan itu merupakan tanggungjawab pribadi atau tanggung jawab Negara.

\section{PEN U T U P}

Berdasarkan apa yang diuraikan maka dapat disimpulkan bahwa Pencatatan perkawinan merupakan suatu hal yang penting yang harus dilakukan oleh setiap pasangan yang menikah untuk itu Negara wajib menjalankan fungsinya sebagai suatu bentuk tanggungjawab kepada masyarakat dalam memberikan pelayanan yang baik untuk mendapatkan hak-hak dalam pencatatan sipil.

Untuk itu dapat disarankan bahwa bila masyarakat tidak melakukan 
pencatatan perkawinan karena kesalahan mereka itu merupakan tanggungjawab mereka namun bila tidak melakukan pencatatan perkawinan karena kesalahan pemerintah selaku aparat dalam menjalankan fungsinya maka, itu merupakan tanggungjawab pemerintah dan pemerintah harus dikenakan sanksi akibat dari kesalahannya.

\section{DAFTAR PUSTAKA}

Anshary, H.M., (2010). Hukum Perkawinan Di Indonesia, Masalah-Masalah Krusial, Yogyakarta: Pustaka Pelajar.

Anshary, H.M., (2014). Kedudukan Anak Dalam Prespektif Hukum Islam Dan Hukum Nasional, Bandung: Mandar Maju.

Hadjon, Philiphus M., (1994). Pengkajian Ilmu Hukum Dogmatik (normatif), Surabaya: Erlangga.

Hadjon, Philipus M. dan Tatiek Sri Djatmiati, (2005). Argumentasi Hukum, Yogyakarta: Gajah Mada Universsity Press.

Hafifah Sj. Sumartono. (2003). Inovasi, Partisipasi Dan GD, Jakarta: Yayasan Obor Indonesia.

Indrati, Maria Farida. (1998). Ilmu Perundang-undangan (DasarDasar dan Pembentukannya), Yogyakarta: Kanisius.

Mubarok, Jaih. (2002). Metodologi Ijtihad Hukum Islam, Yogyakarta: UII Press.

Mubarok, Jaih. (2006). Hukum Islam, Konsep, Pembaruan dan Teori Penegakan, Bandung: Benang Merah Press.

Rahman, Abdul dan Syahrani Ridwan. (1978). Masalah-Masalah Hukum Perkawinan di Indonesia, Bandung: Alumni.

Rahman, Bakri. A. dan Sukarja Ahmad. (1981). Hukum Perkawinan Menurut Islam Undang-Undang
Perkawinan dan Hukum Perdata / $B W$, Jakarta: Hidayah Karya Agung.

Sudarsono. (1994). Hukum Perkawinan Nasional, Jakarta: Rineka Cipta.

Darmabrata, Wahyono. (2003). Tinjauan UU No 1 Tahun 1974 Tentang Perkawinan Beserta UndangUndang dan Peraturan Pelaksanaanya, Jakarta: Gitama Jaya.

\section{Lain-Lain}

http://www. Kompas . com / kompascetak / 0603/25/Jabar/ 764.htm 